ZBIGNIEW ZIOLO

Uniwersytet Pedagogiczny w Krakowie, Polska - Pedagogical University of Krakow, Poland

\title{
Rola edukacji w rozwoju społeczno-gospodarczym i kulturowym
}

\section{The Role of Education in Socio-Economic and Cultural Development}

Streszczenie: $\mathrm{W}$ procesie wkraczania $\mathrm{w}$ informacyjną fazę rozwoju coraz bardziej zaznaczać się będą nowe tendencje w zakresie zmian struktur zawodowych, społecznych i kulturowych. Będą one konsekwencją nasilających się procesów automatyzacji i robotyzacji w działalności produkcyjnej, usługowej i zarządzaniu. Wpłynie to na stopniowe ograniczanie rozmiarów zatrudnienia i likwidację wielu zawodów. Równocześnie pojawiać się będzie coraz większe zapotrzebowanie na kadry o nowych umiejętnościach zawodowych (technicznych, organizacyjnych, zarządzania) oraz rozwiązywania pojawiających się nowych problemów społecznych i kulturowych. Wpływa to na rosnącą rolę edukacji m.in. w zakresie przedsiębiorczości oraz przygotowywania poszczególnych osób i społeczeństwa do nowych wyzwań cywilizacyjnych. Towarzyszy temu pojawianie się nowych przesłanek i tendencji rozwoju społeczno-gospodarczego i kulturowego oraz konieczność działań na rzecz przyspieszania procesów rozwojowych, które omówiono w artykule. W końcowej jego części przedstawiono opinie przedsiębiorców dotyczące funkcjonowania firm.

\begin{abstract}
Upon entering into the information phase of development, new trends in changing professional and social structures and cultural habits will become more and more prominent. They will be a consequence of the increasing automation and robotisation processes in production, service and management activities. This will lead to a gradual reduction in the size of employment and abolition of many professions. At the same time, there will be an increasing demand for staff with new professional skills (technical, organisational, management) and solving of new social and cultural problems. This affects the increasing role of education, among others in the field of entrepreneurship, and preparing individuals and society for new civilization challenges. This is accompanied by the emergence of new premises and tendencies of socio-economic and cultural development, and the need to act to accelerate development processes that have been discussed in the article. The final part presents the opinions of entrepreneurs regarding the functioning of companies.
\end{abstract}

Słowa kluczowe: edukacja; procesy przemian; przedsiębiorczość; przemiany społeczne

Keywords: education; entrepreneurship; social transformations; transformation processes 
Otrzymano: 2 lipca 2020

Received: 2 July 2020

Zaakceptowano: 17 października 2020

Accepted: 17 October 2020

\section{Sugerowana cytacja/Suggested citation:}

Zioło, Z. (2020). Rola edukacji w rozwoju społeczno-gospodarczym i kulturowym. Przedsiębiorczość - Edukacja [Entrepreneurship - Education], 16(2), 7-24. doi: 10.24917/20833296.162.1

\section{Wstęp}

Współcześnie zauważane zmiany struktur zawodowych, społecznych i kulturowych, będące wynikiem m.in. procesu wkraczania w informacyjną fazę rozwoju, powodują zaznaczanie się nowych tendencji. Związane $\mathrm{z}$ nimi procesy wytwarzania i zarządzania $\mathrm{w}$ coraz większym stopniu opierać się będą na wdrażaniu nowych osiągnięć prac naukowych, naukowo-badawczych i wdrożeniowych. Wpłynie to na przemiany metod zarządzania i organizacji działalności produkcyjnej oraz usługowej, a także na relacje ekonomiczne, społeczne, kulturowe i zawodowe. Procesy te dokonywać się będą w warunkach wzrostu mechanizacji, automatyzacji i robotyzacji procesów produkcyjnych oraz działalności usługowej. Przyczynią się do stopniowych przemian współczesnych rynków pracy w drodze eliminowania wielu dotychczasowych stanowisk pracy i likwidowania wielu zawodów, ale równocześnie pojawiać się będzie coraz większe zapotrzebowanie na kadry o nowych umiejętnościach nie tylko zawodowych (technicznych, organizacyjnych, zarządzania), lecz także rozwiązywania pojawiających się nowych problemów społecznych i kulturowych. W przestrzeni światowej procesy te mogą wpływać na zróżnicowanie lub wyrównywanie dysproporcji potencjału gospodarczego poszczególnych kontynentów, krajów, regionów i układów lokalnych (m.in. Kudełko, 2007, 2013). Należy przyjąć, że rozwój technologii i związane z nim zmiany gospodarcze, społeczne i kulturowe będą się coraz bardziej nasilać i nawiązywać do nowych kierunków rozwoju cywilizacyjnego

Kluczowe znaczenie w tym procesie będą mieć odpowiednio przygotowane osoby i społeczeństwo kształcone w procesach edukacyjnych. Poziom i jakość kształcenia na wszystkich poziomach edukacji będą się przyczyniać do wzrostu zasobów intelektualnych poszczególnych osób oraz podnoszenia jakości kapitału ludzkiego i społecznego ${ }^{1}$.

Coraz bardziej złożona i intensywnie rozwijająca się gospodarka oraz związane z nią przemiany społeczno-kulturowe w określonych skalach układów przestrzennych dokonywać się będą z różnym nasileniem. Spowodują one nie tylko zmiany zachowań przedsiębiorstw, ale także gospodarstw domowych i instytucji oraz wdrażanie odpowiedniej polityki rozwoju. W konsekwencji coraz bardziej zwiększać się będzie znaczenie wiedzy z zakresu przedsiębiorczości i konieczność upowszechniania jej w społeczeństwie. Na tym tle w niniejszych rozważaniach zmierzać będziemy do zarysowania roli edukacji jako podstawowego warunku kształtowania postaw przedsiębiorczych społeczeństwa wobec nowych wyzwań rozwoju cywilizacyjnego.

\footnotetext{
${ }^{1}$ W krajach Unii Europejskiej udział osób w wieku 16-74 lat z przynajmniej podstawowymi umiejętnościami cyfrowymi wynosi 85\% w Luksemburgu, 79\% w Holandii, 71\% w Wielkiej Brytanii, 29\% w Bułgarii oraz Rumunii. W Polsce wynosi on $46 \%$.
} 
Rozwijanie edukacji przedsiębiorczości jest bardzo ważnym czynnikiem przygotowującym społeczeństwa i jednostki ludzkie do funkcjonowania w nowej fazie społeczeństwa informacyjnego, w której podstawową bazę potencjalnego rozwoju stanowi nauka, a gospodarka opiera się na wiedzy. W nowych warunkach problematyka ta winna być wdrażana we wszystkich treściach przedmiotów na różnych poziomach edukacji, w tym w edukacji szkolnej. Konieczność rozwijania postaw przedsiębiorczości jest ważna nie tylko dla przyszłych przedsiębiorców, ale także dla osób reprezentujące różne zawody (Makieła, Stuss, 2018; Rachwał, 2019; Zioło, 2010, 2012a, 2019; Zioło, Rachwał, 2019). Należy przyjąć, że wobec nasilających się przemian społecznych, gospodarczych i kulturowych edukacja i kształtowanie przedsiębiorczości stają się jednymi z kluczowych kompetencji dla osób wkraczających nas rynek pracy. Szeroki zakres tej problematyki podejmuje praca zbiorowa dotycząca kształtowania kompetencji przedsiębiorczych (Rachwał, 2019a, Rachwał, 2019b). Problematyka przedsiębiorczość traktowana jest w niej jako kompetencja kluczowa w systemie edukacji (m.in. Kilar, Rachwał, 2019a; Kilar, Rachwał, 2019b; Rachwał, 2019b; Śliwińska, 2019; Wasilczuk, Richert-Kaźmierdka, 2017)

\section{Otoczenie procesu edukacji przedsiębiorczości}

Przyjmujemy, że podstawowym warunkiem rozwoju technologicznego, gospodarczego, społecznego i kulturowego jest dbanie o wzrost innowacyjności. Nowe rozwiązania technologiczne, techniczne, czy doskonalone procesy zarządzania mogą tworzyć i wdrażać tylko odpowiednio przygotowane osoby, które je opracują, wdrożą do produkcji i działalności usługowej oraz podniosą jakość funkcjonowania poszczególnych instytucji na konkurencyjnym rynku. Dlatego korporacje i gospodarka światowa coraz intensywniej poszukują nowych talentów i stwarzają dla nich odpowiednie warunki edukacji oraz przygotowania zawodowego, w celu rozwijania badań podstawowych, prac badawczo-rozwojowych, prac wdrożeniowych, kierowania procesami produkcyjnymi i usługowymi oraz podnoszenia jakości organizacji życia społecznego i kulturowego. Działania te w głównym stopniu wpływają na wzrost konkurencyjności poszczególnych krajów i regionów, stanowią podstawę dla rozwoju gospodarczego, społecznego i kulturowego oraz wpływają na przyciąganie talentów, co przejawia się w tzw. drenażu mózgów. Proces ten jest szczególnie szkodliwy dla obszarów słabiej rozwiniętych, z których odpływają talenty, najczęściej do krajów ekonomicznie rozwiniętych. Z jednej strony ogranicza to możliwości ich własnego rozwoju, a z drugiej strony zwiększa potencjał innowacyjny krajów o wyższym poziomie rozwoju. W przestrzeni światowej pierwsze pozycje w zakresie przyciągania talentów zajmują: Szwajcaria, Singapur i Stany Zjednoczone, a następnie: Norwegia, Szwecja i Finlandia, natomiast Polska w tym rankingu zajmuje dopiero 39 pozycję (tabela 1). Ograniczenie odpływu talentów jest możliwe dopiero przez tworzenie odpowiednich warunków ich rozwoju i wykorzystania w słabiej rozwiniętych krajach macierzystych ${ }^{2}$.

\footnotetext{
${ }^{2}$ Również w Polsce opracowano program mający na celu łączenie polskich studentów i absolwentów uczelni zagranicznych z pracodawcami w kraju. $66 \%$ studentów chce wrócić po studiach do kraju, ale musi mieć na miejscu warunki do wykorzystania zdobytych umiejętności. Jako podstawowe atuty tychże studentów wymienia się: obycie międzynarodowe (88\%), znajomość języków obcych (85\%), umiejętności „miękkie”, projektowe podejście do zadań (63\%) i kontakty z zagranicą (54\%) (Błaszczak, 2019b).
} 
Tabela 1. Konkurencyjność krajów w zakresie przyciągania talentów w 2018 r.

\begin{tabular}{|c|c|c|}
\hline Pozycja & Kraje & Liczba punktów \\
\hline 1 & Szwajcaria & 79,9 \\
\hline 2 & Singapur & 78,4 \\
\hline 3 & USA & 74,3 \\
\hline 4 & Norwegia & 74,3 \\
\hline 5 & Szwecja & 74,0 \\
\hline 6 & Finlandia & 73,8 \\
\hline 7 & Dania & 73,1 \\
\hline 8 & Wielka Brytania & 72,6 \\
\hline 9 & Holandia &. \\
\hline & Estonia & \\
\hline 22 & Czechy & 50,1 \\
\hline & \multicolumn{2}{|c|}{ Polska } \\
\hline 25 & Badania na zbiorze 119 krajów z całego świata \\
\hline \multicolumn{2}{|c|}{} &
\end{tabular}

Źródło: Global Talent Competitiveness Index, za: Błaszczak (2018, 5 lutego)

Zasadniczą rolę w procesie kształcenia talentów odgrywa nauczyciel o odpowiednim przygotowaniu zawodowym i odpowiedniej postawie społecznej. W tej sytuacji podstawowym celem polityki gospodarczej i społecznej musi być dbałość o podnoszenie poziomu edukacji, a nauczyciele powinni stawać się coraz ważniejszą i konkurencyjną grupą zawodową ${ }^{3}$. Niedocenianie ich znaczenia w dobrze zorganizowanym systemie edukacyjnym nie gwarantuje rozwoju innowacyjnej gospodarki i nowoczesnego społeczeństwa. Natomiast tylko głoszenie haseł o konieczności rozwoju innowacyjnej gospodarki i społeczeństwa nie da należytych rezultatów. Dlatego zaniedbywanie rozwiązywania problemów edukacyjnych świadczy o niskich kwalifikacjach zawodowych polityków. Nie rozumieją oni współczesnych tendencji i mechanizmów kształtowania procesów rozwoju cywilizacyjnego, nie mają wyobraźni i umiejętności analizy procesów w dłuższym czasie, często myślą doraźnie o swojej obecności w polityce tylko w jednej lub dwóch kadencjach. Stąd nie czują własnej odpowiedzialności za kształtowanie racjonalnych tendencji rozwoju kraju, regionu, czy układu lokalnego, w nawiązaniu do współczesnych tendencji przemian $^{4}$.

${ }^{3}$ Należy zaznaczyć, że mimo znaczących zaniedbań polscy uczniowie osiągają dobre wyniki w świecie. W 2018 r. w badaniach OECD w czytaniu i interpretacji zajęli czwarte miejsce w Europie (po Estonii, Finlandii, Irlandii), w matematyce trzecie miejsce (po Estonii, Holandii) i w naukach przyrodniczych również trzecie miejsce (po Estonii, Finlandii) (Ćwiek, 2019).

${ }^{4}$ W 2016 r. polscy licealiści na międzynarodowych olimpiadach przedmiotowych zdobyli 25 medali, w tym 3 złote. Wymaga to od nauczycieli wielu godzin pracy, którą dodatkowo wykonują poza czasem swojej pracy dydaktycznej, przy braku wynagrodzenia i bez większego wsparcia finansowego, podczas gdy w 2015 r. dotacje finansowe na letnie sporty olimpijskie wyniosły $175,3 \mathrm{mln}$ zł. Sportowcy otrzymali też wysokie nagrody finansowe za medale olimpijskie i zostali przyjęci przez najwyższe władze państwowe. Tymczasem mistrzowie olimpiad przedmiotowych zostali przyjęci przez wojewodę, który wręczał międzynarodowemu medaliście bon do księgarni o wartości 200 zł (Suchecka, Kulczycka, Czoik, 2016; Leniarski, Wilkowicz, 2016). 
W procesie edukacji przedsiębiorczości podstawowym zagadnieniem staje się dążenie do przygotowania ucznia, studenta, a później dorosłego człowieka do aktywnego i racjonalnego uczestnictwa w kształtującym się społeczeństwie oraz do jego funkcjonowania w zmieniającym się otoczeniu. Szczególną rolę odgrywa zdobywanie określonej wiedzy oraz umiejętności jej wykorzystania, celem pobudzania i rozwijania postaw przedsiębiorczych w warunkach nasilających się przemian gospodarczych, społecznych i kulturowych, w zmieniającym się otoczeniu. Obecni uczniowie i studenci w najbliższym półwieczu swojej aktywizacji zawodowej będą musieli opanować nowe umiejętności realizacji własnych aspiracji oraz planów życiowych i szukać swojego miejsca w szybko zmieniających się uwarunkowaniach przyrodniczych, gospodarczych, biznesowych, społecznych, kulturowych i politycznych, w skali międzynarodow ej, krajowej, regionalnej, a także lokalnej. W procesie przemian nasilać się będą coraz bardziej relacje krajowych układów z otoczeniem międzynawowym, zróżnicowanym pod względem poziomu rozwoju, stopnia nowoczesności gospodarki i produkcji, zasobów kapitałowych, zmieniających się reguł postępowania władzy politycznej poszczególnych krajów, a także światowych centrów decyzyjnych.

Podejmując problematykę roli edukacji przedsiębiorczości, zakładamy, że nasilające się procesy przemian cywilizacyjnych coraz silniej zmieniać będą dotychczasowe struktury zawodowe, społeczne i kulturowe, wykształcone w poprzednich fazach rozwoju społecznego. Dlatego znaczącą rolę w tym zakresie mają dążenia do upowszechnienia i zwiększenia dostępu do edukacji, w tym do edukacji przedsiębiorczości, wdrażanie nowoczesnych treści nauczania, a także wskazywanie i budowanie właściwych postaw osobowościowych i społecznych (rycina 1). Umożliwią one aktywne włączanie się poszczególnych osób, grup społecznych, układów lokalnych i regionalnych w nowoczesne nurty procesów rozwojowych. Dlatego w celu przygotowania poszczególnych osób i społeczeństwa do aktywnego uczestnictwa w nasilającym się procesie rozwoju cywilizacyjnego, w działalności edukacyjnej szczególnie ważnym zadaniem jest dążenie do opanowania: umiejętności kreowania własnej drogi życiowej w nawiązaniu do zarysowujących się tendencji rozwoju w stałych lub zmieniających się uwarunkowaniach politycznych, społecznych, gospodarczych i kulturowych, poznawania i rozumienia zmieniających się tendencji przemian otoczenia oraz uwarunkowań zmian społeczno-gospodarczych i kulturowych różnej skali układów przestrzennych, a także narosłych dysproporcji rozwojowych kontynentów, krajów i regionów. Podstawowe znaczenie ma także opanowanie umiejętności: włączania się w procesy rozwojowe, budowania strategii i podejmowania działań na rzecz skracania dystansu cywilizacyjnego w stosunku do regionów stojących na najwyższym poziomie rozwoju. Rozumienie reguł rozwoju cywilizacyjnego jest także niezbędne, aby umieć zaobserwować i poznawać występujące błędy oraz opanowywać umiejętności unikania błędów potencjalnych, które mogą się pojawić w zmieniających się uwarunkowaniach rozwoju.

Znaczącą rolę w realizacji przedstawionych założeń procesu edukacyjnego odgrywa polityka rozwoju, w której ogólne przesłanki wynikają z dążenia do podnoszenia konkurencyjności kraju, regionów oraz układów lokalnych w drodze wdrażania racjonalnych zasad i kierunków przemian, mających na celu podnoszenie poziomu i jakości życia ludności. Służyć temu powinny różnorodne instytucje oraz instrumenty bezpośredniego i pośredniego oddziaływania.

Podczas wkraczania w informacyjną fazę rozwoju szczególnie ważnym celem i zadaniem społeczeństwa jest kształcenie wysoko kwalifikowanych kadr technicznych 


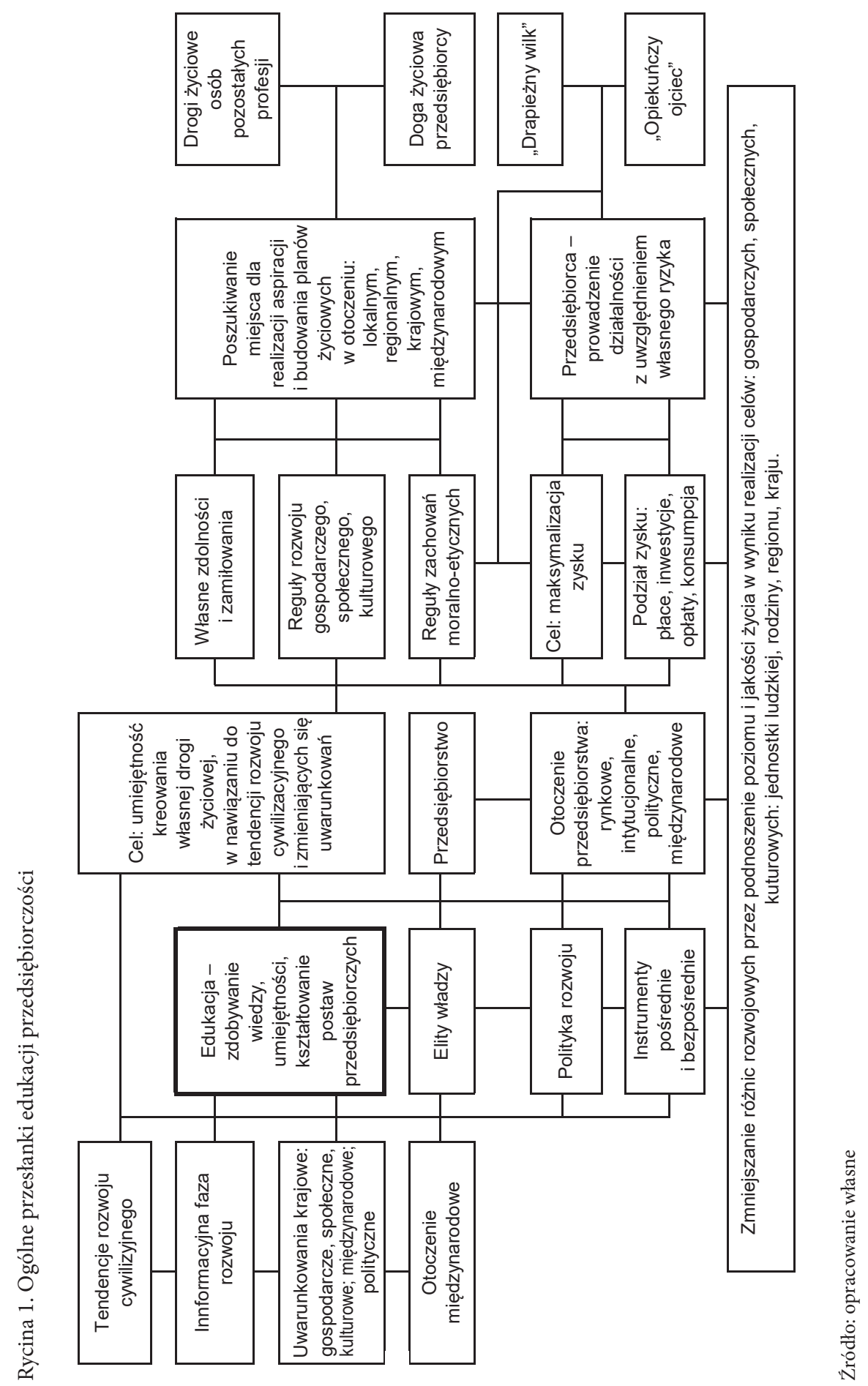


i ekonomicznych jako organizatorów umożliwiających tworzenie i wdrażanie nowych urządzeń, metod produkcji oraz efektywnego zarządzania. Kadry te winny czuć się odpowiedzialne za pozostałą część społeczeństwa i dbać o podnoszenie jego poziomu edukacyjnego i kulturowego, a także podnoszenie poziomu i jakości życia.

Na wszystkich poziomach edukacji szczególną rolę odgrywają poziom i jakość kadr nauczycielskich oraz odpowiednia infrastruktura, które w głównym stopniu decydują o poziomie i jakości kształcenia. Dlatego szczególnie ważnym problemem jest podnoszenie atrakcyjności zawodu nauczyciela oraz przyciągnięcie do pracy odpowiednio uzdolnionych kandydatów. W podstawowym stopniu wpływa na to wysokość nakładów finansowych kierowanych na edukację, w tym odpowiedni poziom płac. Należy przy tym nadmienić, że praca nauczyciela szybko się zmienia i wymaga od niego ciągłego kształcenia, dokształcania i doskonalenia zawodowego w zakresie wprowadzania nowych treści i metod kształcenia oraz wychowania. W procesach edukacyjnych szczególnie ważne staje się opanowanie przez uczniów i studentów umiejętności obserwacji oraz właściwe rozumienie i ocena dokonujących się zmian, a także określanie zarysowujących się tendencji dalszego rozwoju. Umożliwia to aktywne włączanie się absolwentów do uczestnictwa w kreowaniu dalszych zmian rozwoju społecznego, gospodarczego i kulturowego różnej skali układów przestrzennych, szczególnie krajowych, regionalnych i lokalnych. Dlatego przyjmujemy, że podstawową rolę w przygotowaniu poszczególnych osób i społeczeństwa do racjonalnego i aktywnego włączenia się w główny nurt współczesnych i przyszłych procesów rozwoju odgrywa edukacja, w tym edukacja przedsiębiorczości (Zioło, 2012a).

Wzrost gospodarczy w głównym stopniu zależy od przedsiębiorców oraz od uwarunkowań, które stwarza dla nich otoczenie. Dlatego w edukacji przedsiębiorczości, obok wdrażania nowoczesnych treści i metod kształcenia, ważne jest wskazywanie i promowanie odpowiednich postaw, które umożliwią włączanie się w dynamizowanie procesów rozwoju poszczególnych osób, grup społecznych, układów krajowych, regionalnych, a także lokalnych, w celu podnoszenia efektywności działalności gospodarczej, społecznej i kulturowej, w nawiązaniu do racjonalnych kierunków dokonujących się przemian. Dlatego szczególnie ważne jest poznawanie i rozumienie: zmieniających się uwarunkowań rozwoju różnej skali układów przestrzennych, narastających dysproporcji rozwojowych, konieczności podejmowanych działań na rzecz aktywnego uczestnictwa w nasilającym się procesie rozwoju ekonomicznego, społecznego i kulturowego, opanowania umiejętności wykorzystania reguł ekonomicznych dla budowy strategii i podejmowania działań prowadzących do wyrównywania dysproporcji rozwojowych oraz skracanie dystansu cywilizacyjnego w stosunku do regionów stojących na najwyższym poziomie rozwoju. Rozumienie reguł rozwoju cywilizacyjnego jest także niezbędne dla opanowania umiejętności obserwacji i dostrzegania występujących nieprawidłowości oraz unikania potencjalnych błędów, które mogą się pojawić się w budowaniu strategii rozwojowych i we wdrażanych procesach zarządzania.

W procesie dydaktycznym należy zwracać uwagę na różnicowane zdolności i zamiłowania uczniów (studentów), które ogrywają ważną rolę w traktowaniu poszczególnych przedmiotów kształcenia. Wynikają one $\mathrm{z}$ indywidualnych zdolności, określonych aspiracji i zakładanych planów życiowych (Zioło, 1979). W procesie tym, obok powszechnej edukacji postaw przedsiębiorczości, szczególnie ważną rolę odgrywa kształcenie liderów, dbanie o budowanie ich wysokiego poziomu intelektualnego, rozbudzanie wrażliwości na problemy etyczno-moralne, a także przygotowywanie ich do brania odpowiedzialności 
za społeczeństwo i do podejmowania działań w warunkach nasilającej się konkurencji.

Wymaga to ciągłego doskonalenia procesów edukacyjnych na wszystkich poziomach kształcenia, w których obok wiedzy merytorycznej ważną funkcję pełni kształtowanie postaw odznaczających się dążeniem do kreowania umiejętności wdrażania nowych pomysłów oraz chęci bycia przedsiębiorczym. Służy to poszukiwaniu możliwości kreowania nowych rozwiązań i pomysłów prowadzących do podnoszenia pozycji konkurencyjnej poszczególnych osób, firm, układów przestrzennych, a także oferowanych produktów, czy działalności usługowej.

W procesie edukacyjnym należy zwrócić uwagę na fakt, że firma nie funkcjonuje i nie rozwija się samodzielnie, ale jest elementem złożonej struktury społeczno-gospodarczej i kulturowej i wraz z otoczeniem zmienia się w wyniku procesu rozwoju technologicznego, gospodarczego oraz potrzeb rynku. Dlatego ważną rolę w procesie edukacyjnym przedsiębiorczości odgrywa poznanie reguł jej rozwoju w strukturze otoczenia. Firma funkcjonuje zgodnie $\mathrm{z}$ mikroekonomicznymi regułami rozwoju, układy regionalne i branżowe - zgodnie z regułami mezoekonomicznymi, gospodarka krajowa według reguł makroekonomicznych, ugrupowaniami krajów (np. Unii Europejskiej) rządzą reguły megaekonomiczne, natomiast gospodarka światowa zmienia się według reguł ekonomii globalnej. Między określonymi regułami zaznaczają się różnorodne relacje pobudzające rozwój, utrzymujące stagnację lub prowadzące do recesji. Reguły te w odmiennym stopniu oddziałują na funkcjonowanie i rozwój działalności podmiotów gospodarczych, a także na przemiany układów przestrzennych. Wynika to z faktu, że zarówno podmioty gospodarcze, jak i różnej skali układy przestrzenne nie są elementami odosobnionymi, ale należą do bardziej złożonych struktur branżowych, przestrzennych i branżowo-przestrzennych.

Szczególne znaczenie w funkcjonowaniu i rozwoju przedsiębiorstwa odgrywają otoczenie rynkowe, jakość elit politycznych oraz możliwości współpracy z otoczeniem, zwłaszcza otoczeniem międzynarodowym. Głównym celem prowadzenia działalności gospodarczej jest maksymalizacja zysku. W gestii przedsiębiorcy i obowiązujących instrumentów finansowych pozostaje natomiast podział zysku. Generalnie obejmuje on udział: płac, inwestycji, opłat i konsumpcję. W zależności od aktualnej sytuacji i potrzeb przedsiębiorca może dokonywać zmian proporcji jego rozdysponowania. Należy przy tym zaznaczyć, że każdy przedsiębiorca prowadzi działalność gospodarczą na własny rachunek i na własne ryzyko, stąd struktura tego podziału jest bardzo ważna dla możliwości efektywnego funkcjonowania przedsiębiorstwa. W zależności od wyników finansowych, zmieniających się uwarunkowań, możliwości rozwoju firmy oraz uznawanych reguł moralno-etycznych, przedsiębiorcza może przyjmować postawę między dwiema krańcowymi postawami: „drapieżnego wilka” i „opiekuńczego ojca”. Należy jednak przyjąć, że podkreślanie wyłącznie wagi maksymalizacji korzyści ekonomicznych może prowadzić do dehumanizacji pracownika czy zarządzającego firmą. Stąd ważne są także treści określonych wartości etyczno-moralnych uwzględniające miejsce człowieka w kulturze, jego odpowiedzialność za innych ludzi, naród, kraj, region, a także swoją małą ojczyznę.

${ }^{5}$ Problematykę tę z pozycji reguł gospodarki liberalnej prezentuje zbiorowa praca pod red. A. Randa (2016). Zespół autorów dokonuje w niej przeglądu mechanizmów kształtowania się światowej gospodarki kapitalistycznej, głównie w warunkach gospodarki amerykańskiej, oraz genezy kryzysów do pierwszej połowy lat 60. XX w. Krytyczna ocena przedstawionych mechanizmów gospodarki kapitalistycznej może być przydatna dla realizacji procesów rozwoju gospodarki polskiej. 
W realizacji zamierzonych celów rozwoju przedsiębiorstwa, układów przestrzennych oraz poszczególnych osób znaczącą rolę odgrywa racjonalna polityka rozwoju gospodarczego, społecznego i kulturowego, przyjmowana przez odpowiednio przygotowane elity władzy ustawodawczej, związane z nią otoczenie instytucjonalne, jakość przygotowywanych i wdrażanych instrumentów bezpośredniego i pośredniego oddziaływania oraz jakość przedstawicieli władz ustawodawczych i wykonawczych (w tym administracyjnych).

W tych złożonych uwarunkowaniach obecny uczeń czy student musi myśleć o poszukiwaniu najlepszego miejsca dla realizacji własnych aspiracji przez zakładanie racjonalnych planów życiowych w aktualnych i zmieniających się w uwarunkowaniach w bliższej i dalszej przyszłości, z uwzględnieniem możliwości ich realizacji w otoczeniu lokalnym, regionalnym, krajowym czy międzynarodowym. Dotyczy to nie tylko przyszłego przedsiębiorcy, ale także potencjalnych przedstawicieli innych profesji, zwłaszcza zajmujących się działalnością polityczną, polityką społeczno-gospodarczą i otoczeniem instytucjonalnym.

Należy podkreślić, że podstawowym celem funkcjonowania tego złożonego systemu społecznego, gospodarczego i kulturowego winno być podnoszenie konkurencyjności oferowanej produkcji i działalności usługowej przez podmioty gospodarcze oraz podnoszenie atrakcyjności różnej skali układów przestrzennych dla rozwijania działalności gospodarczej, co w drodze racjonalnego zarządzania powinno wpływać na podnoszenie poziomu i jakości życia poszczególnych osób i rodzin. Cele te mogą realizować tylko odpowiednio przygotowani ludzie o odpowiednim poziomie wiedzy i odpowiednich umiejętnościach oraz wyznający odpowiednie reguły postępowania etyczno-moralnego.

\section{Przejawy i konsekwencje braku wiedzy z zakresu edukacji przedsiębiorczości}

Niski poziom edukacji przedsiębiorczości, związany z brakami umiejętności wdrażania instrumentów ekonomicznych, jest poważną barierą dalszego rozwoju działalności gospodarczej i często prowadzi do upadłości firm, zwłaszcza mikrofirm. Przejawem tego są uwagi przedsiębiorców dotyczące możliwości ograniczania i eliminowania obecnych przyczyn upadłości podmiotów gospodarczych (tabela 2). Szczególnie wysoki odsetek respondentów, bo aż 42,0\%, za główną przyczynę upadłości uważa nietrafione inwestycje. Niewątpliwie są one wynikiem braku odpowiedniej edukacji i wiedzy w zakresie czynników lokalizacji firm, braku rozeznania potencjalnych rynków, a także relacji konkurencyjnych, które wpływają na podejmowanie niewłaściwych decyzji inwestycyjnych. Dla wielu przedsiębiorców poważną barierę stanowią zatory płatnicze (39,8\%). Wynikają one w znacznym stopniu z niedoskonałości instrumentów prawnych, nieszanowania zasad etycznych, upadłości kontrahentów, braku kapitału i utraty płynności finansowej. Podobnie nieszanowanie etyki biznesu wpływa na nieuczciwą konkurencję (35,4\%). Na kolejnych miejscach wśród przyczyn upadłości firm znajdują się błędy zarządzających (34,4\%) oraz wydłużanie terminów płatności $(33,2 \%)$. Wiele przyczyn upadłości, szczególnie mikrofirm, można ograniczać m.in. przez: podniesienie poziomu edukacji w zakresie przedsiębiorczości, doskonalenie instrumentów prawnych, podnoszenie poziomu moralno-etycznego przedsiębiorców oraz sprawności władz administracyjnych i politycznych (Keralla Research..., 2018, 6 kwietnia). 
Tabela 2. Powody upadłości firm

\begin{tabular}{|l|c|l|}
\hline \multicolumn{1}{|c|}{ Przyczyny } & \multicolumn{1}{|c|}{$\begin{array}{c}\text { Udział } \\
\text { w procentach }\end{array}$} & \multicolumn{1}{|c|}{$\begin{array}{c}\text { Możliwości eliminowania (osłabiania) } \\
\text { nagatywnych przyczyn }\end{array}$} \\
\hline Nietrafione inwestycje & 42,0 & $\begin{array}{l}\text { edukacja, niewłaściwa ocena lokalizacji, } \\
\text { doradztwo biznesowe }\end{array}$ \\
\hline Zatory płatnicze & 39,8 & produkcyjne, rynek, prawne, etyczne \\
\hline Upadłości kontrahentów & 36,8 & $\begin{array}{l}\text { edukacja, nierozpoznanie kontrahentów, } \\
\text { etyka biznesu }\end{array}$ \\
\hline Nieuczciwa konkurencja & 35,4 & etyka biznesu \\
\hline Błędy zarządzających & 34,4 & edukacja, brak myślenia strategicznego \\
\hline $\begin{array}{l}\text { Wydłużenie terminów } \\
\text { płatności }\end{array}$ & 33,2 & $\begin{array}{l}\text { prawne, etyczne bariery w płynności } \\
\text { finansowej }\end{array}$ \\
\hline \multicolumn{2}{|c|}{264,4 tys. firm nie reguluje płatności terminowo, ich zobowiązania obejmuję 25,2 mld zł } \\
\hline
\end{tabular}

Źródło: Keralla Research... (2018, 6 kwietnia)

Na rozwój działalności inwestycyjnej i produkcyjnej firm negatywnie wpływają niestabilne instrumenty prawne. Trudno liczyć na podnoszenie efektywności działania, jeżeli np. w 2016 r. weszło w życie 10,9 tys. stron aktów prawnych, w tym akt dotyczących spraw: prawno-sądowych $-3,8$ tys., infrastrukturalnych $-2,3$ tys., podatkowych $-1,8$ tys. i produktowych - 1,5 tys. Wśród nich zdarzają się postanowienia nie do końca precyzyjnie sformułowane, które utrudniają ich interpretację i poprawne prowadzenie działalności gospodarczej (Kucharczyk, 2018, 9 lutego).

Niewątpliwie poważną barierą w rozwijaniu działalności dużych firm są także decyzje polityczne związane ze zmianami prezesów i zarządów w spółkach Skarbu Państwa. Od 2009 r. w poszczególnych latach zmiany prezesów wahały się od 15,6\% w 2015 r. do 20,0\% w 2011 r. Brak stabilności na tych stanowiskach nie zachęca do działań podnoszących efektywność gospodarowania i ogranicza przyjmowanie długofalowych strategii rozwoju przedsiębiorstwa. Prezesi wobec niepewności swojej posady w większym stopniu zainteresowani są kształtowaniem poprawnej postawy politycznej i eliminowaniem potencjalnego ryzyka utraty swojego stanowiska aniżeli rozwijaniem działalności firmy.

Brak edukacji z zakresu przedsiębiorczości, w tym z zakresu zagadnień finansowych, w społeczeństwie jest przyczyną wielu błędnych decyzji podejmowanych w gospodarstwach domowych. Wskazuje na to ich zadłużenie z tytułu kredytów mieszkaniowych i konsumpcyjnych (tabela 3). W krajach o wyższym poziomie rozwoju ekonomicznego, w stosunku do PKB, znaczące zadłużenie gospodarstw domowych związane jest $\mathrm{z}$ kredytami mieszkaniowymi; tak jest w: Danii (101,2\%), Szwecji (66,7\%), Holandii $(65,9 \%)$, a także w Wielkiej Brytanii i Luksemburgu. Natomiast gospodarstwa domowe w krajach o niższym poziomie rozwoju odznaczają się najniższymi udziałami kredytów mieszkaniowych: Rumunia $-7,5 \%$, Węgry $-7,9 \%$, Bułgaria - 9,6\%. W Polsce udział ten wynosi $20,3 \%$. W poszczególnych krajach rozwój budownictwa mieszkaniowego wpływa na przyspieszanie cyrkulacji pieniądza w gospodarce i spełnia ważną funkcję w aktywizacji związanych z nim sektorów przemysłowych (produkcji materiałów budowlanych, wyposażenia mieszkań w różnego rodzaju urządzenia), usługowych (prac wykończeniowych), finansowych (kredytowania zakupu mieszkań i ich wyposażenia, wnoszenie odpowiednich podatków) i in. Działania te wpływają na wzrost kapitalizacji jednostek osadniczych oraz na konieczność ich dostosowania do nowych wymogów związanych 
np. z pojawiającym się osiedlem mieszkaniowym przez jego doinwestowanie w zakresie odpowiedniej infrastruktury sieciowej i społecznej.

Odwrotne tendencje zaznaczają się w zakresie kredytów konsumenckich. Najwyższymi wartościami charakteryzują się kraje słabiej rozwinięte: Grecja (15,5\%), Bułgaria $(9,0 \%)$, Polska $(8,9 \%)$. Podczas gdy dla gospodarstw domowych krajów ekonomicznie rozwiniętych wartości wskaźników są niskie: Belgia (2,0\%), Holandia (2,4\%), Chorwacja $(3,1 \%)$. Wysokie wartości wskaźników zadłużenia gospodarstw domowych Cypru wynikają z dużego rozwarstwienia społecznego, w którym istotny wpływ na kredyty wywiera z jednej strony kapitał napływowy, a z drugiej strony - biedniejsze społeczeństwo lokalne. Podobnie niskie wskaźniki Łotwy i Litwy wynikają z odmiennej polityki kredytowej. Należy wnosić, że w krajach o wyższym poziomie rozwoju ekonomicznego gospodarstwa domowe mają większą wiedzę ekonomiczną i kładą większy nacisk na inwestycje trwałe, które są bardziej efektywne. Natomiast w krajach o niższym poziomie mniejsza wiedza ekonomiczna wpływa na podejmowanie mniej racjonalnych decyzji kredytowych. Ponadto wraz ze zwiększaniem się potencjału ekonomicznego kraju zmniejsza się udział wydatków konsumpcyjnych.

Tabela 3. Zadłużenie gospodarstw domowych z tytułu kredytów mieszkaniowych i konsumenckich w stosunku do PKB w procentach

\begin{tabular}{|l|c|l|l|c|}
\hline \multicolumn{1}{|c|}{ Kraje } & $\begin{array}{c}\text { Kredyty } \\
\text { mieszkaniowe }\end{array}$ & & \multicolumn{1}{c|}{ Kraje } & $\begin{array}{c}\text { Kredyty } \\
\text { konsumenckie }\end{array}$ \\
\hline Dania & 101,2 & & Cypr & 12,9 \\
\hline Szwecja & 66,1 & & Grecja & 12,5 \\
\hline Holandia & 65,9 & & Bułgaria & 9,0 \\
\hline W.Brytania & 58,5 & & Polska & 8,9 \\
\hline Cypr & 58,2 & & Portugalia & 7,2 \\
\hline Luksemburg & 55,4 & & Francja & 7,1 \\
\hline Portugalia & 48,7 & & Słowacja & 7,1 \\
\hline Hiszpania & 45,0 & & Finlandia & 6,8 \\
\hline Francja & 43,0 & & Hiszpania & 6,8 \\
\hline Finlandia & 43,0 & & W. Brytania & 6,5 \\
\hline Malta & 41,1 & & Węgry & 6,2 \\
\hline Niemcy & 36,0 & & Rumunia & 6,1 \\
\hline Belgia & 34,7 & & Niemcy & 5,9 \\
\hline Grecja & 33,0 & & Dania & 5,6 \\
\hline Estosnia & 31,0 & & Słowenia & 5,6 \\
\hline Słowacja & 29,9 & & Luksemburg & 5,5 \\
\hline Austria & 29,0 & & Włochy & 5,5 \\
\hline Irlandia & 25,3 & & Austria & 5,1 \\
\hline Czechy & 23,5 & & Czechy & 4,7 \\
\hline Włochy & 21,9 & & Szwecja & 4,5 \\
\hline Polska & 20,3 & & Irlandia & 4,4 \\
\hline Litwa & 17,2 & & Estonia & 3,3 \\
\hline Lotwa & 16,3 & & Malta & 3,2 \\
\hline Chorwacja & 14,6 & & Chorwacja & 3,1 \\
\hline
\end{tabular}




\begin{tabular}{|l|r|l|l|l|}
\hline Słowenia & 13,8 & & Holandia & 2,4 \\
\hline Bułgaria & 9,6 & & Belgia & 2,0 \\
\hline Węgry & 7,9 & & Łotwa & 1,8 \\
\hline Rumunia & 7,5 & & Litwa & 1,5 \\
\hline
\end{tabular}

Źródło: za: Biuro Informacji Kredytowej (2019, 12 września)

W Polsce dobra sytuacja gospodarcza dawała przekonanie, że istnieją większe możliwości rozwoju, pieniądz jest łatwo dostępny i akcja kredytowa znacznie się ożywiła. Wraz ze wzrostem stopy życiowej zwiększały się potrzeby, które wpływały na wzrost zadłużenia Polaków w kredytach konsumpcyjnych z 49 mld zł w 2004 r. do 141 mld zł w 2008 r., a następnie do 156 mld zł w 2016 r. (Bednarek, 2016, 4 listopada; Semczuk, 2012, 10-11 listopada). Łatwy dostęp do kredytu sprawił, że ludzie zaczęli więcej kupować i pożyczać, ponieważ myśleli, że jest ich na to stać. Niestety w wielu wypadkach było to myślenie życzeniowe, niepoparte analizą możliwości zwrotu zaciągniętego kredytu. W konsekwencji według Krajowego Rejestru Długów, Biura Informacji Gospodarczej we wrześniu 2019 r. zaległości finansowe 2,7 mln dłużników wynosiły 54,7 mld zł, a w ciągu ostatnich pięciu lat wzrosły o 182,5\% (Mazurkiewicz, 2019, 2 września; PAP, jk, 2019, 5 sierpnia). Z danych podawanych przez BIG InfoMonitor wynika, że łączna kwota zaległych zobowiązań Polaków na koniec czerwca 2019 r. wynosiła 76,6 mld zł. Najbardziej zadłużona 63-letnia osoba zalegała ze spłatą $70 \mathrm{mln}$ zł. Wśród głównych powodów zadłużania się gospodarstw domowych znajdują się: niskie zarobki (35\%), chęć podniesienia poziomu życia (23\%), niska emerytura (renta), wydatki zdrowotne (po 22\%), pomoc rodzinie (12\%), groźba upadłości konsumenckiej (6\%), brak edukacji (5\%) (Mazurkiewicz, 2019, 2 września). Generalnie zadłużenie gospodarstw domowych wynika $\mathrm{z}$ jednej strony z braku wiedzy, a z drugiej strony - z, chęci podniesienia poziomu życia wobec braku odpowiednich zasobów finansowych. Problem zaczyna się wtedy, gdy brakuje na spłatę raty kredytu i z obawy przed konsekwencjami sięga się po kolejny kredyt. Dlatego wiedza o zadłużeniu jest bardzo istotna dla gospodarstw domowych i osób niezależnie od profesji zawodowych.

Oznacza to, że rozwijanie edukacji ekonomicznej jest niezbędne w życiu każdego człowieka. Wyrazem tego są liczne przykłady obrazujące, jak brak tego typu edukacji wpływa na życie jednostek i społeczeństwa. Gospodarka w przestrzeni światowej staje się coraz bardziej złożona i rozumienie jej, a zwłaszcza gospodarki finansowej, staje się niezwykle ważne w działalności tak mikrofirm, jak i gospodarstw domowych. Edukacja i kształtowanie postaw przedsiębiorczych są więc ważne nie tylko dla osób planujących podejmowania własnej działalności gospodarczej i osób prowadzących już własne firmy. Wiedza, zwłaszcza finansowa, jest niezbędna także dla racjonalnego prowadzenia własnego gospodarstwa domowego. Wyniki badań PZU i Fundacji Młodzieżowej Przedsiębiorczości dotyczące podstaw wiedzy ekonomicznej prowadzone na zbiorowości 3 tys. uczniów szkół ponadgimnazjalnych wskazują, że $33 \%$ badanych nie poradziłoby sobie z otwarciem lokaty oszczędnościowej (Grabek, 2012, 11 września). Ponad 30\% badanych uznało swoją wiedzę dotyczącą problemów finansowych za małą lub bardzo małą. Równocześnie 70\% przyznało, że ta wiedza i umiejętności ludziom w ich wieku są potrzebne. Około 30\% nie zdawało sobie sprawy z zagrożeń i korzyści, które niosą często ze sobą oferowane produkty finansowe. Wiedzę na temat finansów i ubezpieczeń badana młodzież czerpała głównie z programów telewizyjnych $(63,1 \%)$, gazet $(52,0 \%)$, internetu, od rodziców, nauczycieli, 
portali społecznościowych (tabela 4). Natomiast młodzież chciałaby ją zdobywać od nauczycieli $(46,4)$, z programów telewizyjnych $(44,6 \%)$ oraz internetu $(41,0 \%)$. Oznacza to docenianie przez młodzież edukacji szkolnej w zakresie problematyki finansów, ale także wskazuje na ważną rolę edukacyjną środków przekazu, od których młodzież oczekuje rzetelnej informacji z tego zakresu.

Tabela 4. Źródła pozyskiwania przez uczniów informacji o finansach i ubezpieczeniach

\begin{tabular}{|l|c|}
\multicolumn{2}{|c|}{$\begin{array}{c}\text { Pozyskiwanie informacji } \\
\text { nt. finansów i ubezpieczeń }\end{array}$} \\
\hline \multicolumn{1}{|c|}{ źródła informacji } & $\begin{array}{c}\text { procent } \\
\text { odpowiedzi }\end{array}$ \\
\hline Programy TV & 63,1 \\
\hline Gazety & 52,0 \\
\hline Internet & 51,3 \\
\hline Rodzice & 44,9 \\
\hline Nauczyciele & 41,9 \\
\hline Portale społecznościowe & 36,1 \\
\hline Instytucje finansowe & 28,9 \\
\hline Radio & 28,4 \\
\hline Koledzy & 26,7 \\
\hline Kursy & 18,4 \\
\hline
\end{tabular}

\begin{tabular}{|l|c|}
\hline \multicolumn{2}{|c|}{$\begin{array}{c}\text { Skąd chciałbyś pozyskiwać informacje } \\
\text { nt. finansów i ubezpieczeń }\end{array}$} \\
\hline pożądane źródła informacji & $\begin{array}{c}\text { procent } \\
\text { odpowiedzi }\end{array}$ \\
\hline Nauczyciele & 46,4 \\
\hline Programy TV & 44,8 \\
\hline Kursy & 42,8 \\
\hline Internet & 41,9 \\
\hline Instytucje finansowe & 41,7 \\
\hline Gazety & 38,0 \\
\hline Rodzice & 31,2 \\
\hline Portale społecznośćiowe & 31,1 \\
\hline Radio & 25,5 \\
\hline Koledzy & 21,8 \\
\hline
\end{tabular}

Źródło: Grabek (2012, 11 września)

Dlatego w procesie edukacji przedsiębiorczości ważne są zagadnienia racjonalnego dysponowania środkami finansowymi zarówno osobistymi, rodzinnymi, jak i każdego podmiotu gospodarczego. Ważne są umiejętności zarządzania budżetem domowym, zwłaszcza „zachowanie powściągliwości w niekontrolowanych wydatkach”, ponieważ od nadmiernej konsumpcji zaczynają się kłopoty z długami. Stąd ważne jest uodpornienie młodego człowieka na reklamy, które na każdym kroku zachęcają do brania kredytu i zakupu dóbr konsumpcyjnych (Ogonowska, 2020, 13 lutego; Pawlak, 2020; 13 lutego).

\section{Przykład przekształcenia małej firmy w największego producenta na krajowym rynku}

W procesie edukacji przedsiębiorczości ważnym zagadnieniem jest także prezentacja pozytywnych przykładów rozwijania własnej działalności gospodarczej oraz konfrontacja ich z zakładanymi celami kształcenia. W trakcie zakładania i prowadzenia własnej firmy przedsiębiorcy w bardzo wielu przypadkach odnieśli znaczące sukcesy i zdobyli pewne doświadczenie, na podstawie których wskazują pożądane cechy oczekiwane u swoich obecnych i potencjalnych pracowników.

Interesujące spostrzeżenia $\mathrm{z}$ tego zakresu przedstawił właściciel firmy Strunobet-Migacz, Henryk Migacz w rozmowie z Joanną Chrustek. Działalność jego firmy rozpoczęła się w 1989 r. od wytwarzania prostych wyrobów betonowych. W 1997 r. podjęto produkcję słupów betonowych, a w 1999 r. zapoczątkowano współpracę z placówkami naukowymi, głównie z Instytutem Politechniki Wrocławskiej. W wyniku współpracy opracowano nowe technologie produkcji wirowanych słupów strunobetonowych oraz 
skonstruowano i wyprodukowano nowe oryginalne maszyny przeznaczone do ich produkcji. Obecnie wytwarzane przez firmę słupy są powszechnie wykorzystane w liniach przesyłowych energii elektrycznej, a także w trakcji kolejowej. Szczególnie ważnym i nowym osiągnięciem jest słup wysokiego napięcia, który dzięki smukłej sylwetce i niesamowitej wytrzymałości może zastąpić dotychczasowe olbrzymie kratowe konstrukcje stalowe. Firma posiada najnowocześniejszą w Europie linię produkcyjną ultralekkich i niekorodujących, kompozytowych słupów oświetleniowych. O poziomie technologicznym produktów świadczy fakt, że słup o wysokości $10 \mathrm{~m}$ waży jedynie $46 \mathrm{~kg}$, co ma duże znaczenie dla zużycia materiałów i energii oraz ich transportu i prac instalacyjnych. Firma zdobywa już rynki zagraniczne, zwłaszcza krajów ościennych, do których kierowana jest znaczna część produkcji.

Zdaniem H. Migacza, sukces firmy, jej dobra sytuacja techniczna, ekonomiczna i rynkowa są przede wszystkim wynikiem:

- nieustannego dążenia do rozwoju i poszerzenia asortymentu produkcji, często w niesprzyjających warunkach gospodarczych i barierach stawianych przez instytucje lokalne,

- stałego udoskonalania asortymentu, doskonalenia i rozwijania technologicznego produkcji, rozbudowy potencjału produkcyjnego (hale produkcyjne, konstruowanie i produkcja maszyn i urządzeń wg własnych pomysłów i projektów),

- konsekwencji, cierpliwości, niepoddawania się przeciwnościom losu i nieustannego dążenia do założonych celów, z wyznawaniem zasady, że sukces osiąga się ciężką pracą i wytrwałością,

- uczciwości wobec: współpracowników, firm kooperujących, odbiorców, a także społeczności lokalnej,

- zamiłowania do pracy, która winna być równocześnie pasją, ponieważ taka praca nie męczy, a przynosi radość,

- nieustannego poszukiwania nowych rozwiązań i wdrażania nowoczesnych technologii, często opracowywanych w ramach działalności firmy, przy współudziale placówek naukowych i naukowo-badawczych,

- szanowania pracowników i ich doświadczenia, ponieważ tylko w ten sposób można na trwale rozwijać kapitał ludzki firmy i budować jej markę,

- dbania o rozwój działalności firmy, przy czym należy godziwie wynagradzać pracowników, zapewnić im poczucie stabilności zatrudnienia i możliwości rozwoju osobistego, ponieważ stały, fachowy i zaangażowany zespół pracowników dla każdego przedsiębiorstwa (kapitał ludzki) jest wartością bezcenną,

- dbałość o budowanie poprawnych relacji w strukturze załogi, dążenie do identyfikowania się pracowników z firmą oraz wytwarzanie poczucia pewnej odpowiedzialności za jakość produkcji oraz kondycję przedsiębiorstwa,

- przyjęcie zasady, że każdy kolejny produkt kierowany na rynek powinien być perfekcyjnie dopracowany i odznaczać się cechami innowacyjnymi.

Firma tworzy nowe miejsca pracy, a także wpływa na rozwój środowiska lokalnego, wspomagając finansowo młodzieżowe kluby sportowe oraz wiele lokalnych inicjatyw, a także pomagając osobom niepełnosprawnym, przedszkolom i kościołom (Migacz, 2019, 3 września).

Z kolei prezes Zarządu Macro, M. Śliboda, mówi: „dbamy, żeby zatrudniać tylko i wyłącznie osoby o wysokiej świadomości, na odpowiednim poziomie intelektualnym, 
zainteresowane nieustannym rozwojem, ale i tym, co dzieje się dokoła nich. Z nimi można budować odpowiedni model współpracy”. Uważa też, że w procesach edukacyjnych „nadal nie promujemy od najwcześniejszych lat szkolnych takich wartości, jak ambicja, współpraca, rozwiązywanie konfliktów, pozytywne intencje, czy nieustanny rozwój”. Jako wyjściowe założenie przyjmuje, że „firma jest tylko dla ludzi, którzy identyfikują się z kulturą organizacyjną firmy i jej długofalową wizją”. Równocześnie twierdzi, że jego firma oferuje wyższe zarobki niż w sąsiednich firmach: „staramy się dobrze wynagradzać ludzi, aby nie musieli martwić się o kwestie finansowe zarówno oni, jak i ich rodziny oraz czuli wsparcie firmy" (Śliboda, 2019, 8 października).

Trzeba podkreślić, że obaj przedsiębiorcy mają wizję rozwoju działalności firmy i podnoszenia jej konkurencyjności w dalszej perspektywie czasu, a jako znaczący czynnik rozwoju przyjmują rosnącą wartość kapitału ludzkiego.

\section{Uwagi końcowe}

W wyniku kształtowania społeczeństwa informacyjnego światowa przestrzeń gospodarcza, społeczna, kulturowa i polityczna staje się coraz bardziej dostępna i umożliwia natychmiastowe przesyłanie informacji bez względu na odległości fizyczne. Umożliwia to nasilanie przestrzennych powiązań: produkcyjnych, kooperacyjnych, surowcowych, usługowych, technologicznych, technicznych, kapitałowych, finansowych, a także wykorzystywanie rozwijających się zasobów wiedzy i nowych rozwiązań technologicznych. Zastosowanie tych procesów stwarza rosnące zapotrzebowanie na nową jakościowo kadrę pracowniczą i zarządzającą, działającą w coraz bardziej złożonych strukturach przedsiębiorstw, w warunkach zmienności i nasilenia różnorodnych powiązań rynkowych oraz stwarzania nowych relacji społecznych, gospodarczych, kulturowych i politycznych, zarówno w układzie światowym, jak i w układach krajowych, regionalnych i lokalnych.

Dla aktywnego włączania się poszczególnych osób i społeczeństwa w procesy rozwoju podstawowe znaczenie ma edukacja, w tym edukacja w zakresie przedsiębiorczości. Umożliwia ona poznawanie złożonych reguł funkcjonowania i rozwoju podmiotów gospodarczych, ich wzajemnych relacji z otoczeniem w oparciu o reguły rozwoju ekonomicznego i funkcjonowania w określonej skali układów przestrzennych, od skali światowej, przez skale krajowe, do skali regionalnej i lokalnej.

Poznawanie reguł ekonomicznego rozwoju pozwala na wybór określonych strategii i racjonalne kształtowanie procesów w wyniku wdrażania odpowiedniej polityki rozwoju społeczno-gospodarczego i kulturowego za pomocą odpowiednich instrumentów sterujących. W wyniku braku odpowiedniej wiedzy pojawiają się liczne bariery rozwoju przedsiębiorczości, które prowadzą do ograniczenia rozwoju działalności gospodarczej lub jej zaniku, a w konsekwencji do osłabiania tempa rozwoju społecznego, gospodarczego i kulturowego. Szczególną rolę w pobudzaniu procesów rozwoju odgrywają jakość i zasoby wiedzy ekonomicznej władz szczebla centralnego, regionalnego, a także lokalnego, które nie zawsze posiadają umiejętności posługiwania się mechanizmami racjonalnego wspierania działalności biznesowej ${ }^{6}$. Poważną barierą rozwoju przedsiębiorczości jest niska jakość

\footnotetext{
${ }^{6}$ Dobrym przykładem może być powtórzenie przez byłego przedstawiciela władzy państwowej dawnej tezy, że nie wierzy on nadal w politykę przemysłową i uważa, że najlepsza polityka przemysłowa to jej brak (Syryjczyk, 2020, stycznia). Natomiast inni autorzy, oceniając 30 lat procesów transformacji i wdrażania wolnego
} 
kapitału społecznego, przejawiającego się w braku zaufania do władz instytucjonalnych oraz niechętnym stosunkiem do przedsiębiorców i rozwijania działalności gospodarczej. Dlatego szczególnie aktualne jest rozwijanie prac badawczych, które uwzględniać będą analizę zmieniających się uwarunkowań rozwijania działalności gospodarczej na tle jasno określonego celu strategicznego, którym powinno być wkraczanie w informacyjną fazę rozwoju, podnoszenie jakości i poziomu życia społeczeństwa, a także podnoszenie, w układzie międzynarodowym, konkurencyjności gospodarki krajowej, regionalnej czy lokalnej.

\section{Literatura}

References

Balcerowicz, L. (2020, 2 stycznia). To co dobre, stało się w 1990, kolejny rok był trudniejszy (rozmowa K.A. Adamczyka). Rzeczpospolita.

Bednarek, M. (2016, 4 listopada). Pożyczkowe fakty i mity. Gazeta Wyborcza.

Biuro Informacji Kredytowej. (2019, 12 września). Decyzja o kredycie powinna być odpowiedzialna. Rzeczpospolita.

Błaszczak, A. (2019a, 9 lipca). Automatyzacja z ludzką twarzą. Rzeczpospolita.

Błaszczak, A. (2019b, 1 lipca). Zawalczymy o polskie talenty za graniczą. Rzeczpospolita.

Błaszczak, A. (2018, 5 lutego). Słabsza konkurencyjność Polski w walce o talenty. Rzeczpospolita.

Ćwiek, J. (2019, 6 grudnia). PISA: polscy gimnazjaliści rozbili bank. Rzeczpospolita.

Grabek, A. (2012, 11 września). Finansowi analfabeci. Rzeczpospolita.

Karpiński, A. (2018). Prawda i kłamstwa o przemyśle. Warszawa: Fundacja Oratio Recta.

Keralla Research dla BIG InfoMonitor (2018, 6 kwietnia). Oko na gospodarkę. Rzeczpospolita.

Kieżun, W. (2012). Patologia transformacji. Warszawa: Wydawnictwo Poltext.

Kilar, W., Rachwał, T. (2019a). Przedsiębiorczość w edukacji przedszkolnej i szkole podstawowej w warunkach zmian podstawy programowej. W: T. Rachwał (red.), Kształtowanie kompetencji przedsiębiorczych, t. 5. Warszawa: Fundacja Rozwoju Systemu Edukacji, 122-141.

Kilar, W., Rachwał, T. (2019b). Przedsiębiorczość w szkole średniej w warunkach reformy systemu oświaty. W: T. Rachwał (red.), Kształtowanie kompetencji przedsiębiorczych, t. 5. Warszawa: Fundacja Rozwoju Systemu Edukacji, 186-198.

Koźmiński, J. (2020, 2 stycznia). Działań interwencyjnych było sporo, dzisiaj się o nich nie pamięta (rozmowa K.A. Kowalczyka). Rzeczpospolita.

Kucharczyk, K. (2018, 9 lutego). Nowa ustawa uderzy w inwestorów z zagranicy. Rzeczpospolita.

Kudełko, J. (2013). Uwarunkowania rozwoju województw Polski wschodniej jako regionów słabo rozwiniętych. Studia KPZK PAN, t. CLI.

Kudełko, J. (red.). (2007). Uwarunkowania rozwoju rzeszowskiego obszaru metropolitarnego w systemie społeczno-gospodarczym i innowacyjnym województwa podkarpackiego. Prace Komisji Nauk Ekonomicznych, 25.

Leniarski, R., Wilkowicz P. (2016, 23 sierpnia). Nasze drogie medale. Gazeta Wyborcza.

Makieła, Z.J.. Stuss, M.M. (2018). Przedsiębiorczość i zarządzanie innowacjami. Warszawa: Wydawnictwo C.H. Beck.

Mazurkiewicz, P. (2019, 2 września). Zadłużenie Polaków rośnie, choć coraz mniej. Rzeczpospolita.

Metrycki, M. (2018, 12 kwietnia). Uczyć dzieci a nie przedmiotów, rozmawia Piasecki M.. Rzeczpospolita.

Migacz, H. (2019, 3 września). Pracować z pasją, rozmowa z J. Chrustek. Biznes Trendy. Dodatek informacyjno-promocyjny.

rynku, przedstawili szereg instrumentów polityki gospodarczej wpływających na procesy przemian przedsiębiorstw i struktur przemysłowych (Balcerowicz, 2020, 2 stycznia; Koźmiński, 2020, 2 stycznia). Trzeba jednak zaznaczyć, że błędne założenia konieczności braku polityki przemysłowej zostały zweryfikowane w szeregu prac (m.in. Karpiński, 2018; Kieżun, 2012). 
Ogonowska, A. (2020, 13 luty). Wyjść ze spirali rosnącego zadłużenia. Rzeczpospolita. Moje pieniądze.

PAP, jk. (2019, 5 sierpnia). Rośnie zadłużenie Polaków. Podwoiło się w ciągu pięciu lat. Pozyskano z: https://www.polskieradio24.pl/42/276/Artykul/2350702,Rosnie-zadluzenie-Polakow-Podwoilosie-w-ciagu-5-lat

Pawlak, M. (2020, 13 luty). Unikajmy pożyczania na konsumpcję. Rzeczpospolita. Moje pieniądze.

Rachwał, T. (red.). (2019a). Kształtowanie kompetencji przedsiębiorczych, t. 5. Warszawa: Fundacja Rozwoju Systemu Edukacji.

Rachwał, T. (2019b). Przedsiębiorczość jako kompetencja kluczowa w systemie edukacji. W: T. Rachwał (red.), Kształtowanie kompetencji przedsiębiorczych, t. 5. Warszawa: Fundacja Rozwoju Systemu Edukacji, 16-34.

Rand, A. (red.). (2016). Kapitalizm. Nieznany ideał. Poznań: Wydawnictwo Zysk i S-ka.

Semczuk, M. (2012, 10-11 listopada). Niepewny koniec kredytowej smuty w polskich bankach. Gazeta Wyborcza.

Skrzypczak, W. (2019). NATO nie ma wizji przyszłości. Świat Elit, 2, 38-39.

Suchecka, J., Kulczycka, A., Czoik, T. (2016, 23 sierpnia). Młodzi, bardzo zdolni, na medal. Gazeta Wyborcza.

Syryjczyk, T. (2020, 2 stycznia). Nie wierzę w politykę przemysłową. Rozmowa z K.A. Kowalczykiem, Rzeczpospolita.

Sztompka, P. (2019, 27 września). Sześć fundamentów wspólnoty. Rzeczpospolita.

Śliboda, M. (2019, 8 października). Praca dla ludzi z pasją. Rozmowa z T. Czołka. Gazeta Wyborcza. Mój Biznes.

Śliwińska, A. (2019). Formy i metody kształcenia w zakresie przedsiębiorczości w szkole podstawowej. W: T. Rachwał (red.), Kształtowanie kompetencji przedsiębiorczych, t. 5. Warszawa: Fundacja Rozwoju Systemu Edukacji, 156-166.

Turski, Ł. (2019, 17-23 czerwca). Jak się dopasować do nowego świata? Rozmawia R. Walenciak, Przeglą.

Wasilczuk, J., Richert-Kaźmierska, A. (2017). Przedsiębiorczość w edukacji inżynierów - doświadczenia i plany w zakresie edukacji „ku przedsiębiorczości” studentów Politechniki Gdańskiej. Przedsiębiorczość - Edukacja [Entrepreneurship - Education], 13, 352-366.

Zioło, Z. (2019). Zarys uwarunkowań dalszego rozwoju przedsiębiorczości w układach przestrzennych. Przedsiębiorczość - Edukacja [Entrepreneurship - Education], 15(1), 7-18.

Zioło, Z. (2012a). Miejsce przedsiębiorczości w edukacji. Przedsiębiorczość - Edukacja [Entrepreneurship - Education], 8, 10-23.

Zioło, Z. (2012b). Funkcje przemysłu i usług w kształtowaniu gospodarki opartej na wiedzy. W: Problematyka 28. Międzynarodowej konferencji Naukowej nt. „Przemysł i ustugi w rozwoju gospodarki opartej na wiedzy". Kraków - Warszawa: Uniwersytet Pedagogiczny im. Komisji Edukacji Narodowej w Krakowie, Instytut Geografii, Zakład Przedsiębiorczości i Gospodarki Przestrzennej, Polskie Towarzystwo Geograficzne Komisja Geografii Przemysłu, 105-108.

Zioło, Z. (2010). Rola zasobów intelektualnych, kapitału ludzkiego i społecznego w procesach rozwoju obszarów wiejskich. Studia Komitetu Przestrzennego Zagospodarowania Kraju PAN, CXXVII, 9-28.

Zioło, I. (1979). Aspiracje i plany życiowe młodzieży szkół ponadpodstawowych obszaru uprzemysławianego i rolniczego (na przykładzie województwa tarnobrzeskiego). Zeszyty Badań Rejonów Uprzemysławianych, KBRU PAN, 72, 5-141.

Zioło, Z., Rachwał, T. (red.). (2019). Rola przedsiębiorczości w edukacji i rozwoju społeczno-gospodarczym układów lokalnych. Przedsiębiorczość - Edukacja [Entrepreneurship - Education], 15(1).

Zbigniew Zioło, prof. dr hab., Uniwersytet Pedagogiczny im. Komisji Edukacji Narodowej w Krakowie, Instytut Geografii, Katedra Przedsiębiorczości i Gospodarki Przestrzennej, były wieloletni kierownik Zakładu Przedsiębiorczości i Gospodarki Przestrzennej Instytutu Geografii Uniwersytetu Pedagogicznego w Krakowie. Doktor nauk przyrodniczych, dr hab. i prof. nauk ekonomicznych. 
Jego zainteresowania badawcze to: gospodarka przestrzenna, geografia ekonomiczna, polityka społeczno-gospodarcza, ekonomika i polityka rozwoju regionalnego.

Zbigniew Zioło, professor, Pedagogical University of Krakow, Institute of Geography, Department of Entrepreneurship and Spatial Management, former chair of Department of Entrepreneurship and Spatial Management, Institute of Geography, Pedagogical University of Krakow. He holds a DSc title. He is also a professor of Economics. His research interests include: spatial management, economic geography, socio-economic policies, economics and policies of regional development.

ORCID: https://orcid.org/0000-0002-6316-1034

\section{Adres/Address:}

Uniwersytet Pedagogiczny im. Komisji Edukacji Narodowej w Krakowie

Instytut Geografii

Katedra Przedsiębiorczości i Gospodarki Przestrzennej

ul. Podchorążych 2

30-084 Kraków, Poland

e-mail: zbziolo@onet.eu 